\title{
A modified non-liquid nitrogen protocol for extraction of high-quality genomic DNA from the inner bark tissues of Dalbergia cochinchinensis (Fabaceae)
}

\author{
X.C. Mo ${ }^{1}$ and P.P. Wangsomnuk ${ }^{2}$ \\ ${ }^{1}$ Department of Applied Technology, Lijiang Teachers College, Lijiang city, \\ P.R. China \\ ${ }^{2}$ Department of Biology, Faculty of Science, Khon Kaen University, Khon \\ Kaen, Thailand \\ Corresponding author: P.P. Wangsomnuk \\ E-mail: prepua@kku.ac.th
}

Genet. Mol. Res. 20 (2): gmr18836

Received March 21, 2021

Accepted May 18, 2021

Published May 31, 2021

DOI http://dx.doi.org/10.4238/gmr18836

\begin{abstract}
Dalbergia cochinchinensis (Fabaceae) is known as Thai rosewood. It is a Thai native and widespread throughout Thailand. Due to it being a hardwood tree, it became a valuable hardwood tree species for its commercial value for luxury furniture and as a first-class prime timber, which has made it a potentially endangered species. For genetic studies of this tree, we tested four protocols of genomic DNA extraction from the inner bark based on the sodium dodecyl sulfate method and two protocols of the cetyltrimethyl ammonium bromide method. We evaluated the quantity, purity, and integrity of the extracted genomic DNA from 15 genotypes of $D$. cochinchinensis using PCR amplification and restriction enzyme digestion to develop a protocol for this species. We found that optimal concentrations of lithium chloride and polyvinylpyrrolidone could improve the quantity and quality of DNA in the extraction buffer without using liquid nitrogen. The highest concentration of high-quality DNA was obtained with protocol M5 (392 $\mathrm{ng} / \mu \mathrm{L}$ DNA and a purity ratio of $\mathrm{A}_{260} / \mathrm{A}_{280}$ equal to 1.96). In contrast, the commercial Nucleospin Plant II Mini Kit provided the lowest yield of $13.94 \mathrm{ng} / \mu \mathrm{L}$ DNA, with a low purity ratio of $\mathrm{A}_{260} / \mathrm{A}_{280}$ (1.58). Start codon targeted and sequence-related amplified polymorphism fingerprints further demonstrated that protocol M5 developed for inner
\end{abstract}


bark tissue samples gives good DNA quality and quantity for genetic studies of D. cochinchinensis.

Key words: Dalbergia cochinchinensis; Endemic species; Genomic DNA extraction; Inner bark

\section{INTRODUCTION}

The conservation of vulnerable species is an essential strategy for preserving biodiversity levels in the world, especially in tropical regions with high biodiversity. However, illegal logging and unbridled deforestation can dramatically destroy such biodiversity, causing a breakdown in the balance of forest renewal (Amaral et al., 2004). Hence, conservation efforts around the world have focused on enhancing biodiversity. It is therefore first of all necessary to accurately identify plant species in order to facilitate their conservation and management. In general, the morphological characters of plant species are the preferred way to conduct the identification of plant species. Also, the identification of plant species requires an expert botanist who is good in genus recognition based on morphological characteristics such as flowers, leaves, and fruits. However, plant species identification remains limited by the plant growth cycle and field investigation, although the morphological characters are a suitable way to discriminate. In some species-rich or taxonomically complex groups, accurate identification is often quite difficult for endemic plant species, especially in cases where other species exist that are very similar but do not face any threat, or in cases where only certain components of the plant can be considered threatened (Webb et al., 2010; Hartvig et al., 2015). Accordingly, it is important to produce novel tools that are capable of providing an accurate means of plant species identification.

The genus Dalbergia encompasses approximately 250 species ranging from shrubs to trees, (Lock et al., 1994; Niyomdham et al., 1997; Lewis et al., 2005). The plants in this genus usually possess very high-quality timber that can be used for house construction, luxury furniture and high-quality music instruments (Soonhuae, 1993). This makes it a highly endangered genus. The 17th Convention on International Trade in Endangered Species of Wild Fauna and Flora (Sheikh and Corn, 2016) provides a list detailing all of the Dalbergia spp. species. Among them, a species known as rosewood, called $D$. cochinchinensis, is naturally distributed in tropical regions throughout Thailand, Vietnam, Laos and Cambodia (Liangsiri et al., 1993; Niyomdham, 2002). Overexploitation and illegal logging may further dramatically aggravate the decrease of this species in the field. The bark of this species forms a remarkable traded Dalbergia, for its extremely slow growth, which has caused it to become a species facing near-extinction (Liangsiri et al., 1993). In general, trees of the genus Dalbergia are very tall and reach 20 to 30 meters. Further, the leaves are also usually infected by fungus and very hard to analyze. It is quite difficult to get enough young healthy leaves to isolate the DNA to qualify for molecular analysis. Thus, the inner fresh bark of genus Dalbergia is a viable and reliable resource of genomic DNA isolation throughout the year. Furthermore, a new way to ensure the species identification of genus Dalbergia must be developed without leaves to fight the illegal logging of Dalbergia spp. However, bark tissue typically comprises from $10-20 \%$ of woody vascular plant varieties by weight, and its content includes tannins, lignin, suberin and suberin, along with several biopolymers and polysaccharides. These chemicals would normally inhibit the 
enzymatic reaction and lead to unsuccessful molecular analysis. Furthermore, lignin comprises around $40 \%$ of the bark tissue, and serves to support the overall structure through crosslinks which connect the various polysaccharides, including cellulose (Vane et al., 2006). Polysaccharides can influence PCR amplification by inhibiting Taq DNA polymerase (Demeke and Adams, 1992; Schrader et al., 2012). It is difficult to get rid of these impurities during the process of isolation. Once oxidized, the polyphenols subsequently bind to the DNA, which limits the potential for the DNA to undergo downstream processing such as the restriction of digestion or the amplification of PCR (Sahu et al., 2012).

Molecular markers have proven to be an efficient method for identifying plants and typically show enough variation to allow different species to be distinguished (Hebert et al., 2003). The principal benefit of applying a method based on DNA is that samples can be identified without the need for expertise in taxonomy, while the tissue samples used can be very small and may be obtained from any part of the organism in question. The most important stage in any technique based on DNA is that of isolating and then amplifying the genomic DNA which is obtained from the plant tissues. Genomic DNA isolation protocols have been reported by numerous publications inferred from different plant species. However, it is still necessary to develop protocols for the extraction of DNA from certain problematic species (Cingilli and Akcin, 2005). Within the plant tissue, many compounds of plant cell wall will strongly inhibit DNA extraction and cause the failure of following molecular analysis, such as polysaccharides, proteins, and phenolic compounds (Finkeldey et al., 2010).

In this study, we develop a modified SDS-based method for isolation genomic DNA of the dried inner bark of D. cochinchinensis collected from Thailand without liquid nitrogen. The inner bark sample collection, pretreatment, storage and the DNA isolation protocol are also described and 15 genotypes of $D$. cochinchinensis from Kohn Kaen province were employed to test the efficiency of the protocol. The performance of the protocol was compared to commercial DNA isolation kits and two CTAB-based DNA isolation methods with leaves and dried inner bark. We hoped to provide an alternative and effective protocol for harvesting high-quality genomic DNA from dried inner bark for molecular studies of trees of the family Fabaceae.

\section{MATERIAL AND METHODS}

\section{Sample collection}

Fresh inner bark samples from 15 genotypes (KK1 to KK15) of D. cochinchinensis in Khon Kaen Province, Thailand were collected using rubber tapping scissors. All samples were air-dried at room temperature overnight and grounded by using a Philips juice dispenser HR2115 (with four-way blades, impact crusher, and 600-watt motor power) until fine tissue was obtained. This finely grounded bark was stored at $-20^{\circ} \mathrm{C}$ until use.

\section{SDS-based extraction protocol}

The SDS-based extraction protocol described below was developed for genomic DNA extraction from the inner bark powder of $D$. cochinchinensisis. Different 
concentrations of $\mathrm{LiCl}$ and PVP were added to the developed extraction buffers to obtain the high-quality genomic DNA (Table 1). To qualify the developed SDS-based extraction protocol, two fundamental CTAB-based protocols modified from Porebski et al. (1997) and Novaes et al. (2009) were also employed to test the applicability of the developed protocols (Wangsomnuk et al., 2014), whereas the lysis agent was replaced by CTAB to isolate the samples. DNA samples were generated by the developed extraction protocols and comparisons from inner bark of $D$. cochinchinensis were further identified by molecular analysis.

Table 1. Details for the components of extraction buffers in the extraction protocols.

\begin{tabular}{|c|c|}
\hline Protocols & Components \\
\hline M1 & $10 \mathrm{mM}$ Tris- $\mathrm{HCl} \mathrm{pH} 8.0,50 \mathrm{mM}$ EDTA, $1.5 \%$ SDS, $2 \% \mathrm{PVP}, 1.2 \% \beta$-mercaptoethanol \\
\hline M2 & $10 \mathrm{mM}$ Tris-HCl pH 8.0, $50 \mathrm{mM}$ EDTA, $50 \mathrm{mM} \mathrm{LiCl}, 1.5 \%$ SDS, $2 \% \mathrm{PVP}, 1.2 \% \beta$-mercaptoethanol \\
\hline M3 & $10 \mathrm{mM}$ Tris- $\mathrm{HCl} \mathrm{pH} 8.0,50 \mathrm{mM}$ EDTA, $100 \mathrm{mM} \mathrm{LiCl}, 1.5 \%$ SDS, $2 \% \mathrm{PVP}, 1.2 \% \beta$-mercaptoethanol \\
\hline M4 & $10 \mathrm{mM}$ Tris-HCl pH 8.0, $50 \mathrm{mM}$ EDTA, $150 \mathrm{mM} \mathrm{LiCl}, 1.5 \%$ SDS, $2 \% \mathrm{PVP}, 1.2 \% \beta$-mercaptoethanol \\
\hline M5 & $10 \mathrm{mM}$ Tris- $\mathrm{HCl} \mathrm{pH}$ 8.0, $50 \mathrm{mM}$ EDTA, $300 \mathrm{mM} \mathrm{LiCl}, 1.5 \%$ SDS, $2 \% \mathrm{PVP}, 1.2 \% \beta$-mercaptoethanol \\
\hline M6 & $10 \mathrm{mM}$ Tris- $\mathrm{HCl} \mathrm{pH} 8.0,50 \mathrm{mM}$ EDTA, $1 \mathrm{mM} \mathrm{LiCl}, 1.5 \%$ SDS, $2 \% \mathrm{PVP}, 1.2 \% \beta$-mercaptoethanol \\
\hline M7 & $10 \mathrm{mM}$ Tris- $\mathrm{HCl} \mathrm{pH} 8.0,50 \mathrm{mM}$ EDTA, $300 \mathrm{mM} \mathrm{LiCl}, 1.5 \%$ SDS, $0.1 \% \mathrm{PVP}, 1.2 \% \beta$-mercaptoethanol \\
\hline M8 & $10 \mathrm{mM}$ Tris- $\mathrm{HCl} \mathrm{pH}$ 8.0, $50 \mathrm{mM}$ EDTA, $300 \mathrm{mM} \mathrm{LiCl}, 1.5 \%$ SDS, $0.5 \% \mathrm{PVP}, 1.2 \% \beta$-mercaptoethanol \\
\hline M9 & $10 \mathrm{mM}$ Tris- $\mathrm{HCl} \mathrm{pH}$ 8.0, $50 \mathrm{mM}$ EDTA, $300 \mathrm{mM} \mathrm{LiCl}, 1.5 \%$ SDS, $1 \% \mathrm{PVP}, 1.2 \% \beta$-mercaptoethanol \\
\hline M10 & $10 \mathrm{mM}$ Tris- $\mathrm{HCl} \mathrm{pH} 8.0,50 \mathrm{mM}$ EDTA, $300 \mathrm{mM} \mathrm{LiCl}, 1.5 \%$ SDS, $1.5 \% \mathrm{PVP}, 1.2 \% \beta$-mercaptoethanol \\
\hline M11 & $300 \mathrm{mM} \mathrm{LiCl}, 1.5 \% \mathrm{SDS}, 2 \% \mathrm{PVP}, 1.2 \% \beta$-mercaptoethanol \\
\hline M12 & $50 \mathrm{mM}$ EDTA, $300 \mathrm{mM} \mathrm{LiCl}, 1.5 \% \mathrm{SDS}, 2 \% \mathrm{PVP}, 1.2 \% \beta$-mercaptoethanol \\
\hline M13 & $10 \mathrm{mM}$ Tris-HCL pH 8.0, $300 \mathrm{mM} \mathrm{LiCl}, 1.5 \%$ SDS, $2 \% \mathrm{PVP}, 1.2 \% \beta$-mercaptoethanol \\
\hline
\end{tabular}

\section{Procedures:}

1. $0.05 \mathrm{~g}$ of the finely-ground inner bark powder sample was added to $750 \mu \mathrm{L}$ of extraction buffer (Table 1) by using SDS as lysis agent.

2. Repeated blending of the mixture was performed prior to incubation for $1 \mathrm{~h}$ at a temperature of $65^{\circ} \mathrm{C}$, with inversion on occasion.

3. The addition of $500 \mu \mathrm{L}$ of chloroform: isoamyl alcohol $(24: 1, \mathrm{v} / \mathrm{v})$ to the extracted system was followed by gentle mixing.

4. Then the tubes were placed in the centrifuge for $5 \mathrm{~min}$ at room temperature and $10,000 \mathrm{rpm}$, whereupon the supernatant was moved to a different tube, followed by steps 3 and 4 being carried out once again.

5. Once the steps for purification had been carried out repeatedly, the aqueous phase was then moved into a different tube. An equal quantity of isopropanol and $200 \mu \mathrm{L}$ of $1.2 \mathrm{M}$ $\mathrm{NaCl}$ were then introduced to the supernatant before the DNA was precipitated via mixing through an inversion process.

6. The tubes were then placed in the centrifuge once again for $10 \mathrm{~min}$ at room temperature and 10,000 rpm. The supernatant was then removed.

7. Rinsing of the pellet was performed on two occasions using $250 \mu \mathrm{L} 70 \%$ ethanol before further centrifuging at $10,000 \mathrm{rpm}$ at room temperature for a period of 5 minutes.

8. After the removal of the supernatant, air-drying of the pellet was completed. 
9. The pellet was subsequently dissolved using $100-\mu \mathrm{L}$ sterile deionized water. The RNA was digested for 30 min at a temperature of $37^{\circ} \mathrm{C}$ with RNase A (Sigma). required.

10. The DNA which had been extracted was placed in storage at $-20^{\circ} \mathrm{C}$ until

Critical details: 1. Add $\beta$-mercaptoethanol to the extraction buffer immediately before use to decrease the possibility of oxidation.

2. Use only freshly prepared extraction buffer.

\section{Commercial DNA extraction protocols}

For comparison with the developed protocols, three commercial genomic DNA extraction kits were employed to extract the same samples to qualify the new protocols. The various commercially available extraction techniques for genomic DNA were performed in line with the instruction guidelines for the DNeasy Plant Mini Kit (Qiagen), E.Z.N.A ®Plant DNA Kit (Omega Bio-tek, USA), and NucleoSpin Plant II Mini Kit (MACHEREYNAGEL GmbH \& Co. KG, Germany). However, when using the E.Z.N.A ${ }^{\circledR} P l a n t$ DNA Kit (Omega Bio-tek, USA), and NucleoSpin Plant II Mini Kit (MACHEREY-NAGEL GmbH\& Co. KG, Germany), isopropanol was used instead of ethanol. The genomic DNA extracted by three commercial protocols was then evaluated and qualified, as detailed in the following description.

\section{DNA extraction from the leaves of $D$. cochinchinensis}

For further estimation of the developed protocols, the young leaves of $D$. cochinchinensis were also subjected to the best protocol that identified the inner bark materials. Here, we used $0.05 \mathrm{~g}$ of fresh leaves of $D$. cochinchinensis to extract the genomic DNA under the best protocol (protocol M5, see Table 1). The extraction procedure was the same as a description of the SDS-based extraction protocol (previous SDS-based procedure description).

\section{DNA quantification and qualification}

The genomic DNA quantities were assessed using a NanoDrop spectrophotometer (Thermo Scientific Co. Ltd). This approach relies upon taking a measurement of the absorbance at $260 \mathrm{~nm}$. The genomic DNA quality was then evaluated through the measurement of the $\mathrm{A}_{260} / \mathrm{A}_{280}$ ratios, while isolated DNA integrity underwent detection through $1 \%$ agarose gel electrophoresis in $1 \mathrm{X}$ Tris borate-EDTA (TBE) buffer and staining with ethidium bromide prior to examination when exposed to ultraviolet light.

\section{SCoT marker fingerprinting}

Thirty-six primers (Collard and Mackill, 2009) were synthesized and screened with genomic DNA from the bark of selected D. cochinchinensis genotypes to test their performance. After that, four primers (Table 2) were chosen to perform amplification on KK1 to KK15 DNA samples of D. cochinchinensis population. A template based on $100 \mathrm{ng}$ of genomic DNA was applied in the context of a $10 \mu \mathrm{L}$ PCR reaction system. The PCR 
reaction mixture of $10 \mu \mathrm{L}$ comprised $1 \mathrm{x}$ buffer $\left(160 \mathrm{mM}\left(\mathrm{NH}_{4}\right)_{2} \mathrm{SO}_{4}, 500 \mathrm{mM}\right.$ Tris-HCl, $\mathrm{pH}$ 9.1, $17.5 \mathrm{mM} \mathrm{MgCl}_{2}$ and $0.1 \%$ Triton X-100; Vivantis), $0.2 \mathrm{mM} \mathrm{dNTP} \mathrm{mix,} 0.2 \mu \mathrm{M}$ of each of the primers, and 0.4 unit $/ 10 \mu \mathrm{L}$ of Taq DNA polymerase (Vivantis). The Agilent 8800 (Germany) was used for the PCR amplification stage, whereby the amplification program involved $3 \mathrm{~min}$ of pre-denaturalization at $95^{\circ} \mathrm{C}$, followed by 40 cycles consist of denaturalization for $1 \mathrm{~min}$ at $95^{\circ} \mathrm{C}$, before annealing for a period of $1 \mathrm{~min}$ at $50^{\circ} \mathrm{C}$, and then extension for $2 \mathrm{~min}$ at $72^{\circ} \mathrm{C}$. This was followed by a final single extension cycle for $5 \mathrm{~min}$ at $72^{\circ} \mathrm{C}$. Agarose gel electrophoresis was employed for the analysis of the PCR products, while the images were obtained and visualized via the Gel Documentation Essential System (Uvitec, Cambridge).

\section{SRAP marker fingerprinting}

The amplification reaction was performed with a few modifications to the method of Li and Quiros (2001). Five primer pairs (Table 2) were chosen from 34 designed primers (Li and Quiros, 2001; Sun et al., 2007) that were pre-screened to test the efficiency of amplification of selected DNA samples. Those chosen primer pairs were then applied to perform the following amplification on entire DNA samples from both the bark and leaves of 15 accessions. An amplification template based on $100 \mathrm{ng}$ of genomic DNA drawn from each of the individuals was employed in a $10 \mu \mathrm{L}$ PCR reaction system. The PCR reaction mixture comprised $1 x$ buffer $\left(160 \mathrm{mM}\left(\mathrm{NH}_{4}\right)_{2} \mathrm{SO}_{4}, 500 \mathrm{mM}\right.$ Tris- $\mathrm{HCl}, \mathrm{pH} 9.1,17.5 \mathrm{mM}$ $\mathrm{MgCl}_{2}$ and $0.1 \%$ Triton X-100; Vivantis), $0.5 \mu \mathrm{M}$ of each of the primers, $0.2 \mathrm{mM} \mathrm{dNTP}$ mix, and 0.4 unit $/ 10 \mu \mathrm{L}$ of Taq DNA polymerase (Vivantis). The Agilent 8800 (Germany) was used to perform PCR amplification, while the amplification program opened with a 3 minute pre-denaturalization phase at $95^{\circ} \mathrm{C}$ followed by 5 cycles consist of denaturalization in duration of $1 \mathrm{~min}$ at $95^{\circ} \mathrm{C}$, before 1 minute of annealing at $35^{\circ} \mathrm{C}$ followed by $2 \mathrm{~min}$ at $72^{\circ} \mathrm{C}$ for extension. Next came 35 cycles of denaturalization for 1 min at $95{ }^{\circ} \mathrm{C}$, before 1 min of annealing at $50^{\circ} \mathrm{C}, 2 \mathrm{~min}$ of extension at $72^{\circ} \mathrm{C}$. This was followed by one final extension cycle of $5 \mathrm{~min}$ at $72^{\circ} \mathrm{C}$. Agarose gel electrophoresis was employed for the analysis of the PCR products, while the images were obtained and visualized via the Gel Documentation Essential System (Uvitec, Cambridge).

Table 2. Parameters of SRAP and SCoT primers used to qualify the extracted genomic DNA of 15 genotypes of Dalbergia cochinchinensis.

\begin{tabular}{llll}
\hline Primer name & Sequences (5'-->3') & $\boldsymbol{T}_{\mathbf{m}}\left({ }^{\mathbf{0}} \mathbf{C}\right)$ & $\mathbf{C G}(\mathbf{\%})$ \\
\hline SRAP primers & ATTCAAGGAGAGTGCGTGG & 60.0 & 53 \\
BG23 & GAGAAAGGTATGAGTTGAAC & 56.3 & 40 \\
BG56 & TCAAGGGCAGGTAAGAACAA & 58.4 & 45 \\
FC1 & CGCAAGACCCACCACAA & 54.6 & 59 \\
SA7 & & 58.4 & 59 \\
ODD4 & AGGGTAGCG TCTGAGGA & 54.9 & 66 \\
SCoT primers & & 50.3 & 55 \\
SCoT20 & ACCATGGCTACCACCGCG & 54.9 & 66 \\
SCoT24 & CACCATGGCTACCACCAT & 52.6 & 61 \\
SCoT25 & ACCATGGCTACCACCGGG & & \\
SCoT26 & ACCATGGCTACCACCGTC & & \\
\hline
\end{tabular}

Abbreviation: SRAP, sequence-related amplified polymorphism; SCoT, start codon targeted. 


\section{Restriction digest estimation}

For further estimation of the quality of extracted genomic DNA by developed protocols, the restriction enzyme digest was applied for extended application of the genomic DNAs. Two restriction enzymes, Pst I-HF and $M s p \mathrm{I}$ were employed to perform the digest verification. The reaction was carried in a $40 \mu \mathrm{L}$ reaction system consisting of $5 \mu \mathrm{g}$ of each genomic DNA sample from the selected protocols with $2 \mu \mathrm{L}$ of $20 \mathrm{X}$ Pst $\mathrm{I}-\mathrm{HF}$ or $M s p \mathrm{I}$ enzyme (NEB), $4 \mu \mathrm{L}$ of $10 \mathrm{X}$ NEB Cutsmart buffer and sterile deionized $\mathrm{H}_{2} \mathrm{O}$ in a $40 \mu \mathrm{L}$ final volume. The reaction was performed at $37^{\circ} \mathrm{C}$ overnight. Subsequently, agarose gel electrophoresis was performed to analyze the product from the reaction, making use of 0.7 $\%$ agarose gel (Agarose Molecular Biology Grade Vivantis Technology Sdn. Bhd., Malaysia). Electrophoresis was carried out with $1 \times \mathrm{TBE}$ buffer which contained $1 \mu \mathrm{g} / \mathrm{mL}$ of ethidium bromide (EtBr) while the voltage was held constant for $4 \mathrm{~h}$ at $50 \mathrm{~V}$. This allowed visualization of the digested DNA, where upon the Gel Documentation Essential System (Uvitec, Cambridge) was used to produce the images.

\section{Data analysis}

Each DNA sample from different developed protocols was tested in five replicates. One-way ANOVA analysis was conducted by using Statistic 8 software program Analytical Software (2003), while Least Significant Difference was employed to determine mean separation in the case of the F-test scores proving significant at the level of 0.05 .

\section{RESULTS AND DISCUSSION}

\section{Protocol design and DNA yields}

In this study, we describe a newly developed protocol that shows high performance for extracting genomic DNA from the inner bark of $D$. cochinchinensis. The developed protocol can remove inhibiting compounds like polyphenol, tannin, secondary metabolite during the DNA extraction process. Fragment analysis revealed that the DNA quality was sufficient to perform the SCoT and SRAP DNA fingerprint analysis by using the dried inner bark samples from 15 genotypes of $D$. cochinchinensis (Figures 1, 2 and 3). Normally, researchers employ commercial kits such as DNeasy Plant Pro Kit and DNeasy Plant Mini Kit (Qiagen) to fast extraction of the genomic DNA from different forms of plant matter in a short time (high phenolic compound leaves or fresh and dried wood). However, such kits could be effective for purity, but would result in low DNA yield (Jiao et al., 2012; Yu et al., 2017; Pipan et al., 2018). It is reported that Yu et al. (2017) succeeded in obtaining genomic DNA by using the DNeasy Plant Mini Kit (Qiagen) with average DNA quantities of 18.9, 10.6 and $28.8 \mathrm{ng} / \mathrm{mg}$ from sapwood, heartwood, and twigs, respectively. However, when the DNeasy Plant Mini Kit (Qiagen) was applied to extract the genomic DNA from the inner bark of $D$. cochinchinensis, it only harvested half the DNA amount (169.92 ng/ $\mu \mathrm{L}$ DNA) of that of our developed protocol M5 (Table 3). Various commercially available kits for the isolation of DNA required an additional buffer that contained PVP, $\beta$-mercaptoethanol, and EDTA at very low temperatures in order to be effective (Kalinowska et al., 2012; Broberg and McDonald, 2019). To estimate the efficiency of the developed methods for the inner 
bark of D. cochinchinensis, we employed three commercial kits for genomic DNA extraction from the samples provided in line with the guidelines of the equipment provider: NucleoSpin Plant II Mini Kit (Macherey-Nagel), E.Z.N.A. ${ }^{\circledR}$ Plant DNA Kit (Omega Bio-tek), and DNeasy Plant Mini Kit (Qiagen). We also investigated the lysis chemical components that contributed to the yield of genomic DNA, such as SDS and CTAB based methods.
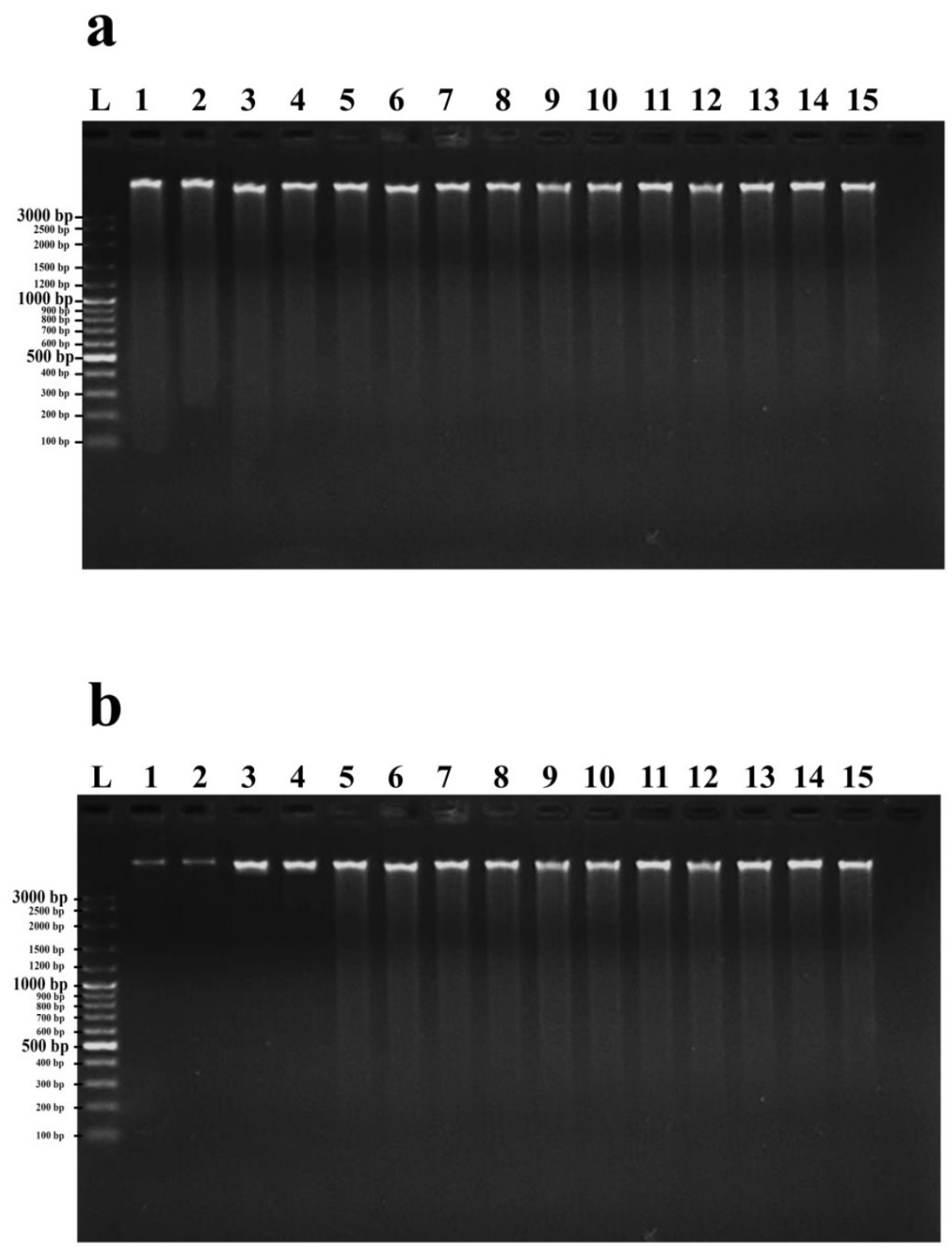

Figure 1. Agarose gel electrophoresis visualization of extracted genomic DNA of 15 genotypes of Dalbergia cochinchinensis. a, dried bark; b, fresh leaves. 

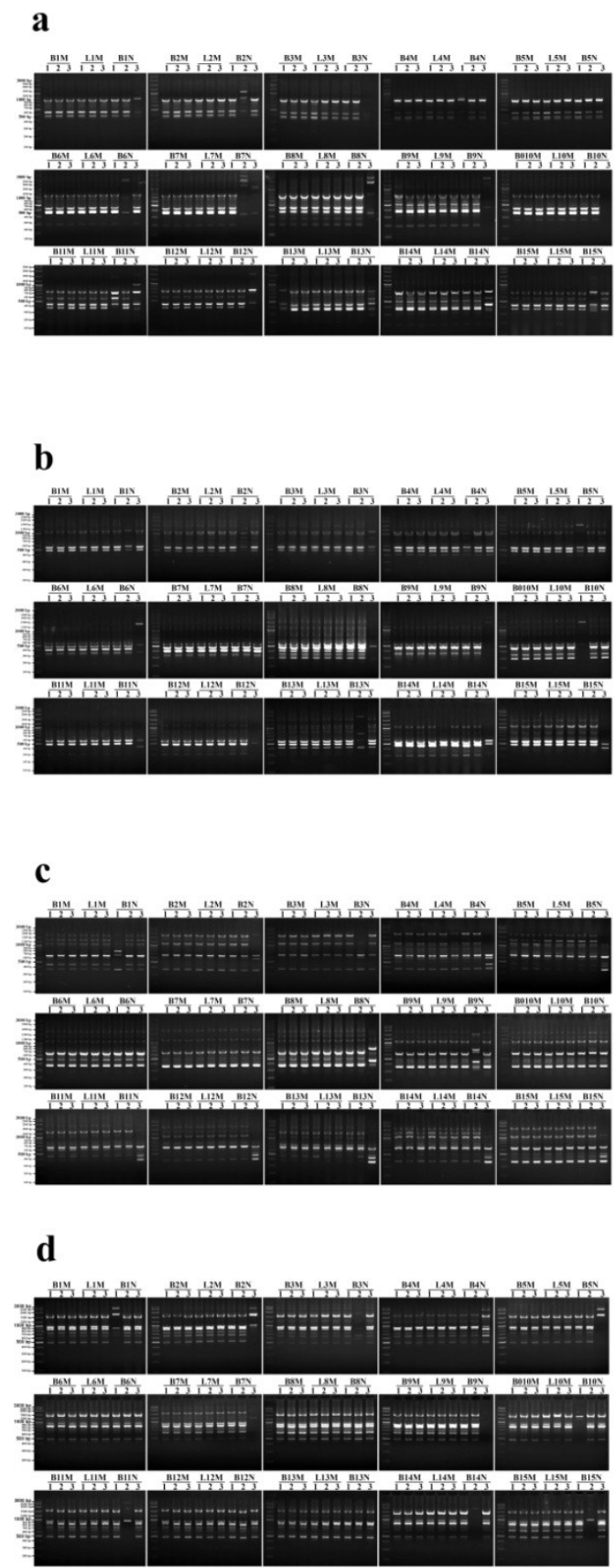

Figure 2. SCoT-DNA fingerprints amplified by SCoT20, SCoT24, SCoT25 and SCoT26 primers of 15 individuals in Figures $2 \mathrm{a}, 2 \mathrm{~b}, 2 \mathrm{c}$ and $2 \mathrm{~d}$, respectively. Letters above the Figures are abbreviations showing the DNA extraction methods from bark (B) or leaf (L) tissue using the developed protocol (M5) and modified Novase et al. (2009) (N). Three replicates from each DNA sample were amplified. Numbers on the left side of the Figure are the sizes (bp) of 100 bp DNA ladder Plus (Vivantis). Abbreviation: SCoT, start codon targeted. 
a

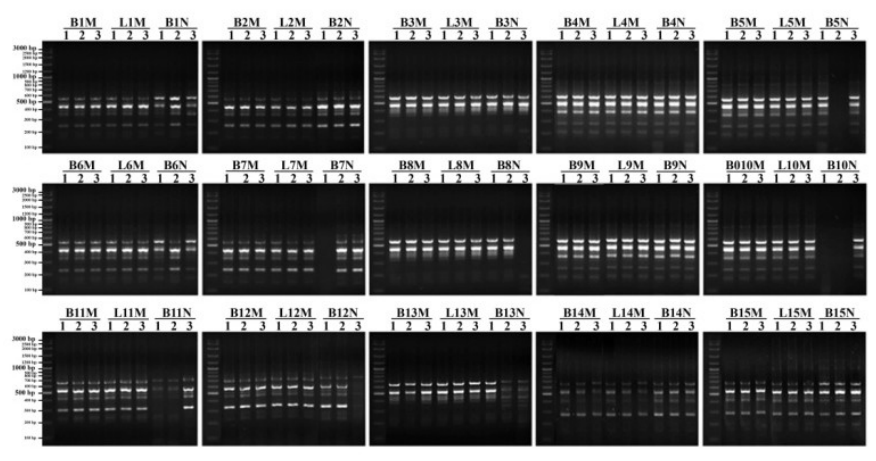

b

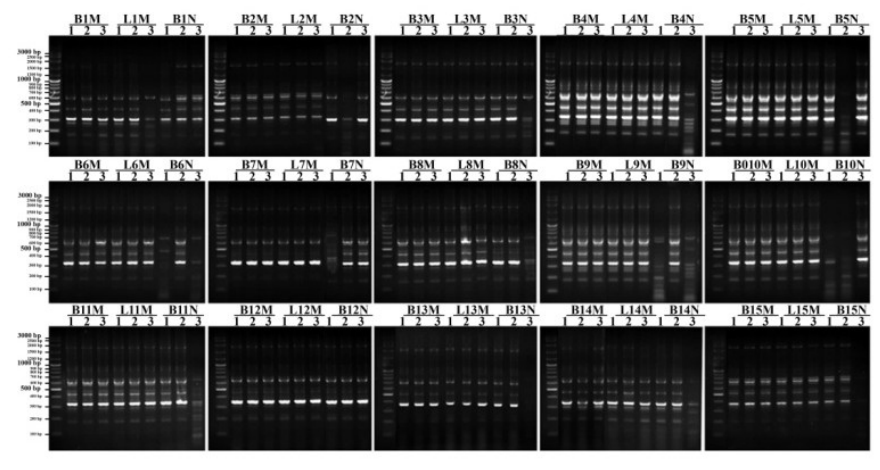

c

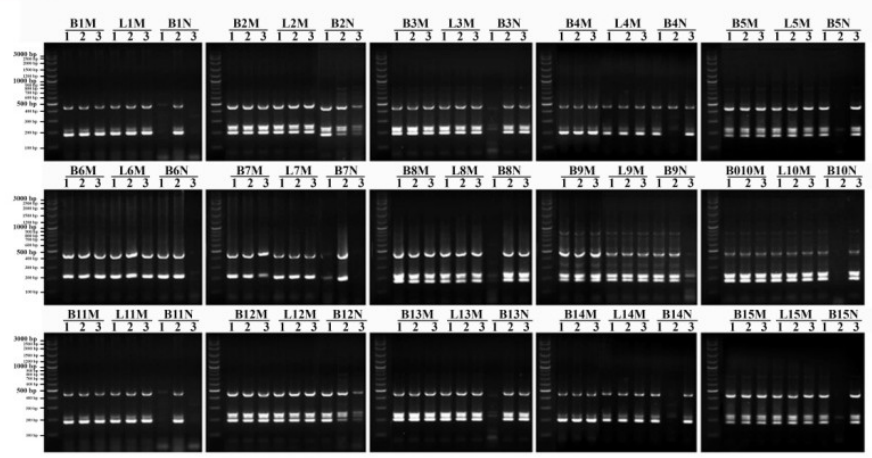

Figure 3. SRAP-DNA fingerprints amplified by FC1-BG23, SA7-BG56 and BG56-ODD04 combinations of 15 samples in Figures $3 \mathrm{a}, 3 \mathrm{~b}$ and $3 \mathrm{c}$, respectively. Letters above the Figure are abbreviations showing the DNA extraction methods from bark (B) or leaf (L) tissue using the developed protocol (M5) and modified Novase et al. (2009) (N). Three replicates from each DNA sample were amplified. The values to the Figure's left indicate the sizes (bp) for the 100 bp DNA ladder Plus (Vivantis). Abbreviation: SRAP, sequence-related amplified polymorphism. 
It is usually the case that the samples of plant matter, such as bark or leaves, will undergo pre-treatment, often involving grinding to a powder, which allows the release of plant cell DNA through the use of liquid nitrogen (Cota-Sánchez et al., 2006; Ali et al., 2019), though some reports do not (Swetha et al., 2014). Here, to low down the cost of extraction and easy to access, we preferred the extracted protocol without liquid nitrogen. A Philips juice dispenser HR2115 was employed to get the fine powder of dried bark and young leaves. To get efficient DNA to perform the molecular studies verification, we also compared the initial amount of grinding bark samples during the DNA extraction process (data not shown). Results showed that $0.05 \mathrm{~g}$ of dried bark in $750 \mu 1$ extraction buffer by the developed protocols could obtain a sufficient yield and quality of genomic DNA, broadly in line with the results from other protocols (Jiao et al., 2012; Swetha et al., 2014; Fatima et al., 2018), which suggested that the developed protocol might help a researcher save more money and easy to get sufficient DNA in a very short period.

\section{Quantitative evaluation}

To obtain the high-quality genomic DNA, the additive amount of some reagents was also investigated within the developed protocols such as $\mathrm{LiCl}, \beta$-mercaptoethanol and PVP. The results indicated that the optimum concentration of $\mathrm{LiCl}$ in SDS-based extraction buffer was $300 \mathrm{mM}$, whereas a lower or higher concentration of $\mathrm{LiCl}$ would lead to lower DNA yields. Although adding optimum LiCl could improve the DNA yield of dried bark, there were also some contaminants like phenols to inhibit the downstream analysis of crude genomic DNA; they could not be removed during the chloroform purification process. $\beta$ mercaptoethanol and PVP are able to assist in eliminating the tannins and polyphenols which can be found in the crude extract and purify the DNA (Horne et al., 2004). Thus, the concentration of these two reagents were also investigated within the extraction buffer systems.

According to the description of Heikrujam et al. (2020), 1.2\% (v/v) of the $\beta$ mercaptoethanol was used and varied concentrations of PVP were added to the extraction buffer system in different protocols to get the optimum concentration to balance the yield and quality of the DNA (Table 1). Results showed that various amounts of PVP could affect the DNA yield. A lower concentration of PVP would lead to lower DNA yield and 2\% concentration of PVP was proven to be optimal. The extracted DNA ratios for $\mathrm{A}_{260} / \mathrm{A}_{280}$ proved to be suitable for each of the protocols for the entire inner bark samples of $D$. cochinchinensis. When the ratio of $\mathrm{A}_{260} / \mathrm{A}_{280}$ was in the range of 1.93-1.99, the extracted DNAs showed high-quality from the individuals. Normally, Tris buffer is used to steady the solution $\mathrm{pH}$ value, allowing the stabilization of the DNA molecules after the breaking of the membranes and cell walls as the tissue is ground. Then, as compartmentalization comes to an end, the release of the cytoplasmic material will release (Heikrujam et al., 2020). Also, beside steadying the $\mathrm{pH}$ value, the Tris buffer system in the developed protocols was also employed to estimate the DNA yield and quality. When protocol M11 and M12 were omitted to add $10 \mathrm{mM}$ Tris- $\mathrm{HCl}(\mathrm{pH} \mathrm{8.0)}$ in the extraction buffer, they gave lower DNA yields where protocol M13 could generate nearly two fold more with the same quality (Table 1) (Sambrook and Russel, 2001). Hence, Tris buffer not only steadied the pH value to stabilize the DNA molecules, it also could influence the DNA yields of the extraction process. Thus, the protocol M1 to M10 added $10 \mathrm{mM}$ Tris- $\mathrm{HCl}(\mathrm{pH} \mathrm{8.0)}$ to the DNA 
extraction buffer system, which showed good performance during the DNA extraction process. Also, the NanoDrop instrument and agarose gel electrophoresis were employed to qualify and verify the DNA quality from different developed protocols (Bessetti, 2007).

Previous studies suggested the DNAs obtained from bark tissue were in the range of $50 \mathrm{ng} / \mu \mathrm{L}$ DNA, according to Asif and Cannon (2005) to 5-8.1 $\mu \mathrm{g}$ DNA/g dried tissue according to Swetha et al. (2014). Here, we developed 13 protocols to extract the DNA from the dried bark tissue of D. cochinchinensis (Table 1), where two modified protocols of Novaes et al., (2009), Porebski et al., (1997), along with three commercially available kits were employed to draw comparisons concerning the quantity and quality of the target DNA. DNA yields were found to fall within the range of $13.94-392.00 \mathrm{ng}$ DNA per $50 \mathrm{mg}$ of homogenized dry bark matters (Table 3 ).

Table 3. Qualification and purity of genomic DNA generated by different extraction protocols by using 50 mg inner bark tissue samples of Dalbergia cochinchinensis.

\begin{tabular}{lll}
\hline Protocols & Quantification $(\mathbf{n g} / \boldsymbol{\mu} \mathbf{L})$ & Ratios $\left(\mathbf{A}_{\mathbf{2 6 0}} / \mathbf{A}_{\mathbf{2 8 0}}\right)$ \\
\hline M1 & $167.65^{\mathrm{f}}$ & $1.98^{\mathrm{b}}$ \\
M2 & $271.80^{\mathrm{cd}}$ & $1.99^{\mathrm{b}}$ \\
M3 & $284.07^{\mathrm{c}}$ & $1.95^{\mathrm{bcd}}$ \\
M4 & $359.10^{\mathrm{b}}$ & $1.95^{\mathrm{bcd}}$ \\
M5 & $392.00^{\mathrm{a}}$ & $1.96^{\mathrm{bcd}}$ \\
M6 & $205.80^{\mathrm{e}}$ & $1.94^{\mathrm{cd}}$ \\
M7 & $65.85^{\mathrm{h}}$ & $1.95^{\mathrm{bcd}}$ \\
M8 & $77.08^{\mathrm{h}}$ & $1.93^{\mathrm{cd}}$ \\
M9 & $112.12^{\mathrm{g}}$ & $1.94^{\mathrm{cd}}$ \\
M10 & $263.53^{\mathrm{d}}$ & $1.94^{\mathrm{d}}$ \\
M11 & $63.07^{\mathrm{h}}$ & $1.94^{\mathrm{dd}}$ \\
M12 & $76.67^{\mathrm{h}}$ & $1.94^{\mathrm{cd}}$ \\
M13 & $103.88^{\mathrm{g}}$ & $1.94^{\mathrm{cd}}$ \\
Modified Novaes et al. $(2009)$ & $276.68^{\mathrm{cd}}$ & $1.91^{\mathrm{d}}$ \\
Poreski et al. (1997) & $112.92^{\mathrm{g}}$ & $1.96^{\mathrm{bc}}$ \\
Nucleospin Plant II Mini Kit & $13.94^{\mathrm{i}}$ & $1.58^{\mathrm{f}}$ \\
E.Z.N.A. B Plant DNA Kit & $97.50^{\mathrm{g}}$ & $1.75^{\mathrm{e}}$ \\
DNeasy Plant Mini Kit & $169.92^{\mathrm{f}}$ & $2.09^{\mathrm{a}}$ \\
LSD & $.000^{*}$ \\
\hline Values which are significantly different according to LSD are indicated by differing letters in each column $(\mathrm{p} \leq 0.05)^{(1)} *$ Indicates \\
significance at the P $\leq 0.05$ level. & &
\end{tabular}

Results showed that protocol M5 gave the highest DNA yield of $392.00 \mathrm{ng} / \mu \mathrm{L}$, which was more than 2 folds of that from QIAGEN DNeasy Plant Mini Kit $(169.92 \mathrm{ng} / \mathrm{\mu L}$ DNA in $50 \mathrm{mg}$ dried inner bark samples), while NucleoSpin Plant II Mini Kit (13.94 ng/ $\mathrm{L}$ DNA in $50 \mathrm{mg}$ dried inner bark samples) gave the lowest DNA yield. Further examination of the extracted DNA also proved the developed protocol M5 showed high performance in the DNA extraction from the inner bark of D. cochinchinensis, where the commercial kits failed to get both high-quantity and high-quality DNA (Table 3). Accordingly, the protocol M5 was chosen for the genomic DNA extraction from both of bark and leaf samples of 15 $D$. cochinchinensis genotypes. According to the previously described DNA extraction procedure in protocol M5, the extracted DNA from the bark was harvested in ranges from 276.37 to $421.10 \mathrm{ng} / \mu \mathrm{L}$ DNA and 317.07 to $1367.10 \mathrm{ng} / \mu \mathrm{L}$ DNA from leaves, respectively. The ratios of $\mathrm{A}_{260} / \mathrm{A}_{280}$ from the bark and leaves are shown in Table 4. Results indicated the success of the extraction of high-quality genomic DNA from the bark and leaves using the 
protocol M5. Subsequently, the integrity of DNAs was evaluated through agarose gel electrophoresis analysis, as shown in Figure 1, which proved that the polysaccharides could be eliminated during the extraction procedure by protocol M5 (Sablok et al., 2009). Some studies reported that it is impossible to observe the extracted DNA from the bark of certain plants such as Cunninghamia lanceolate and Dipterocapaceae on agarose gel as a consequence of the partial degradation occurs (Rachmayanti et al., 2006; Tang et al., 2009; Jiao et al., 2012).

Table 4. Summary of results of the DNA obtained from 15 genotypes of Dalbergia cochinchinensis.

\begin{tabular}{|c|c|c|c|c|c|}
\hline $\begin{array}{l}\text { Genotypes } \\
\text { Bark }\end{array}$ & DNA Conc. $(\mathrm{ng} / \mu \mathrm{L})$ & $\begin{array}{l}\text { DNA quality } \\
\left(A_{260} / A_{280} \text { ratio }\right) \\
\text { Leaf }\end{array}$ & Sample & DNA Conc. $(n g / \mu L)$ & $\begin{array}{l}\text { DNA quality } \\
\left(\mathbf{A}_{260} / \mathbf{A}_{280} \text { ratio }\right)\end{array}$ \\
\hline KKU01 & 353.37 & 1.95 & KKU01 & 676.37 & 2.09 \\
\hline KKU02 & 370.13 & 1.94 & KKU02 & 317.07 & 2.08 \\
\hline KKU03 & 368.03 & 1.93 & KKU03 & 467.10 & 2.09 \\
\hline KKU04 & 367.43 & 1.93 & KKU04 & 841.53 & 2.09 \\
\hline KKU05 & 364.60 & 1.93 & KKU05 & 467.23 & 2.08 \\
\hline KKU06 & 276.37 & 2.09 & KKU06 & 676.37 & 2.14 \\
\hline KKU07 & 397.07 & 2.08 & KKU07 & 497.07 & 2.14 \\
\hline KKU08 & 367.10 & 2.09 & KKU08 & 1367.10 & 2.16 \\
\hline KKU09 & 374.87 & 2.09 & KKU09 & 574.87 & 2.12 \\
\hline KKU10 & 313.90 & 2.08 & KKU10 & 727.23 & 2.08 \\
\hline KKU11 & 352.70 & 2.19 & KKU11 & 576.37 & 2.09 \\
\hline KKU12 & 397.07 & 2.08 & KKU12 & 497.07 & 2.08 \\
\hline KKU13 & 421.10 & 2.09 & KKU13 & 467.10 & 2.09 \\
\hline KKU14 & 371.53 & 2.09 & KKU14 & 874.87 & 2.09 \\
\hline KKU15 & 387.23 & 2.08 & KKU15 & 1400.57 & 2.08 \\
\hline
\end{tabular}

\section{Molecular analysis}

Due to the limited information regarding the genetic pattern of $D$. cochinchinensis in Thailand, few conclusions can be reached concerning genetic diversity, screening for superior germplasm, or indeed for resource protection. PCR amplification is important to prove the quality of DNA in this case; reproducibility is one of the most important for the marker of choice. Full digestion using a two-enzyme GBS protocol (Pst I/MspI) which offered enhanced complexity reduction in comparison to the use of the original protocol based on ApeKI (Poland et al., 2012) confirmed the purity of the isolated DNA (Figure 4). In this study, we use of the polymorphism and reproducibility of a pair of multi-locus markers based on PCR technique, SCoT and SRAP by the PCR amplification of extracted genomic DNA template, isolated from $15 \mathrm{D}$. cochinchinensis individuals according to the developed protocol M5 (Figures 2 and 3). Data shown that these extracted genomic DNA by protocol M5 could work well in this dominant marker systems and present the high polymorphism within the $D$. cochinchinensis population without existing genome sequences (Aneja et al., 2012; Robarts and Wolfe, 2014). The generation of SCoT markers had their basis in a short-conserved region which flanked the start codon (ATG) in the gene sequences of $D$. cochinchinensis, which employs 18-mer long primers (Collard and Mackill, 2009) that were successfully amplified in other plants to explore their genetic variability (Agarwal et al., 2019; El-Aziz et al., 2019). Thirty-six SCoT primers and 30 combinations of SRAP primers were screened for analysis on the genomic DNA of selected $D$. 
cochinchinensis genotypes. Finally, 4 SCoT primers and 3 SRAP primer combinations were chosen for further genetic analysis based on the clear amplicons (Table 2). Nearly $100 \%$ reproducibility of both SCoT and SRAP fingerprints with distinct banding patterns of more than 50 loci were presented by using the extracted genomic DNA as templates from leaves and inner barks of $15 \mathrm{D}$. cochinchinensis genotypes which extracted by our developed protocol M5 (Figures 2 and 3). Under the SCoT and SRAP-DNA molecular marker techniques, it was possible to identify whether each sample was identical or similar to any of the 15 individuals. Also, restrict enzymes digest indicated that the genomic DNA was free from contaminants. However, the fingerprint remarks of extracted genomic DNA from 15 individuals by using the modified method according to the description by Novaes et al. (2009) failed to be repeatable (Figures 2 and 3). Interestingly, both SCoT and SRAP primers were found to give efficiency and informative polymorphic variety, which could be used for genetic diversity evaluation within $D$. cochinchinensis populations (Figures 2 and 3). Both PCR and restriction digest further proved that the extracted genomic DNA by protocol M5 was suitable for the molecular studies.

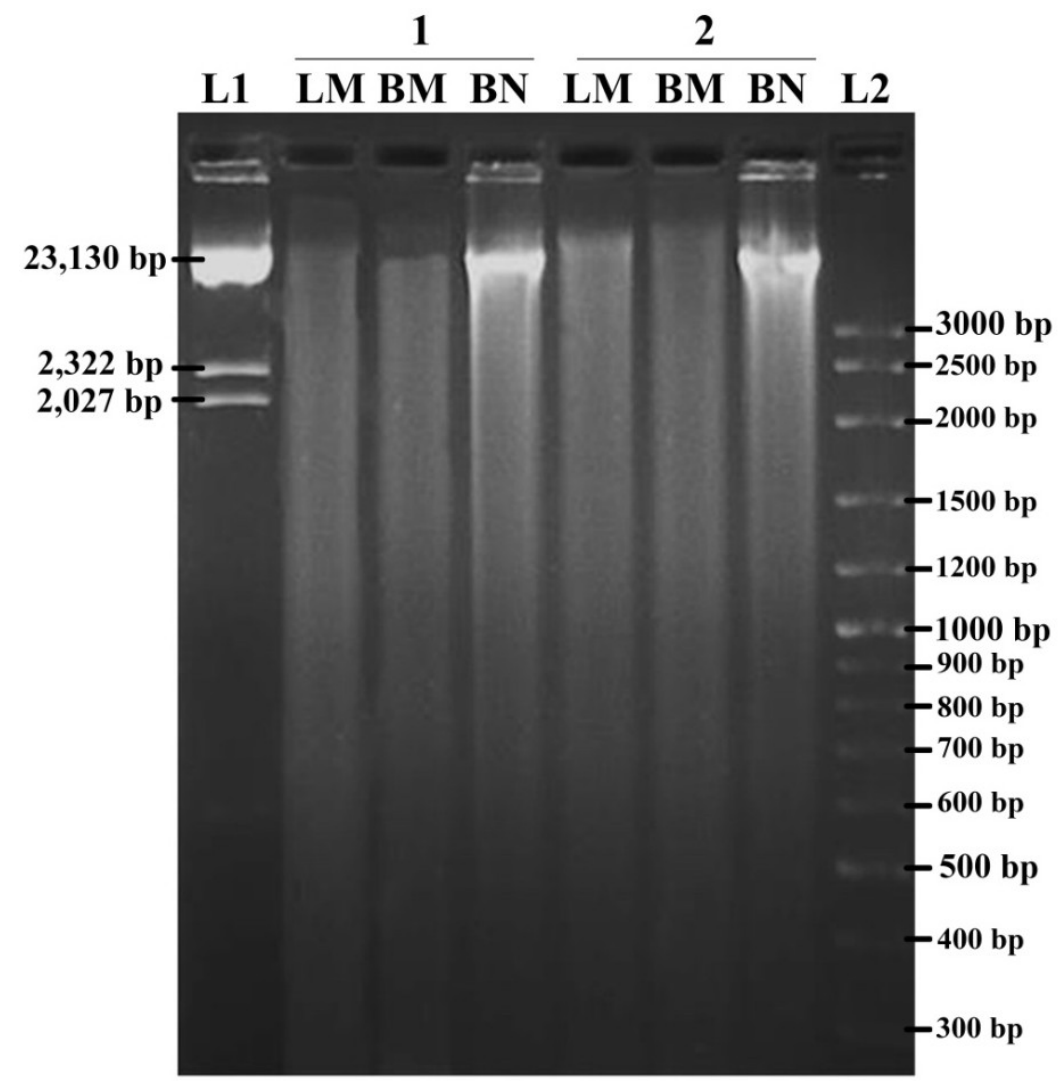

Figure 4. Agarose gel electrophoresis of the restriction digest of the genomic DNA obtained from the dried inner bark and fresh leaf matter of D. cochinchinensis via protocol 5 (LM and BM, respectively) compared to the modified method of Novase et al. (2009) (BN). M1 and M2 were Lambda Hind III (Promega) and 100 bp DNA ladder plus (Vivatis), respectively. LM, DNA extracted from leaf; BM, DNA extracted from dried inner bark; BN, DNA extracted from inner bark based on the modified Novaes et al. (2009) method. 


\section{CONCLUSIONS}

Here, we present a newly-developed SDS-based genomic DNA extraction protocol with comprehensive analysis of DNA yield and quality, PCR amplification, and restriction enzyme digest compared to commercial kits and CTAB-based method. Protocol M5 was the most effective. By using this protocol, the DNA extracted from the inner bark of $D$. cochinchinensis could be used for restriction enzymes digests and PCR reactions. Our research could help to obtain sufficient high-quality genomic DNA from the inner bark and other tissues for genetic structure studies and conservation of $D$. cochinchinensis.

\section{ACKNOWLEDGMENTS}

We thank journal reviewers for their valuable comments on an early version of this manuscript. This work was funded by Khon Kaen University and the Plant Genetic Conservation Project under The Royal Initiation of Her Royal Highness Princess Maha Chakri Sirindhorn.

\section{CONFLICTS OF INTEREST}

The authors declare no conflict of interest.

\section{REFERENCES}

Agarwal A, Gupta V, Haq S UI, Jatav PK, et al. (2019). Assessment of genetic diversity in 29 rose germplasms using SCoT marker. J. King Saud. Univ. Sci. 31: 780-788.

Ali Q, Salisu IB, Raza A, Shahid AA, et al. (2019). A modified protocol for rapid DNA isolation from cotton (Gossypium spp.). MethodsX. 6: 259-264.

Amaral W, Kjaer E, Yanchuk A and Graudal L (2004). Research needs. In: FAO, FLD, IPGRI (eds) Forest genetic resources conservation and management: overview, concept and some systematic approaches, vol 1. International Plant Genetic Resources Institute, Italy, pp. 37-48.

Analytical Software (2003). Statistix 8 analytical software user's manual. Analytical Software, Dallas, TX.

Aneja B, Yadav NR, Chawla V and Yadav RC (2012). Sequence-related amplified polymorphism (SRAP) molecular marker system and its applications in crop improvement. Mol. Breeding. 30: 1635-1648.

Asif MJ and Cannon CH (2005). DNA extraction from processed wood: a case study for the identification of an endangered timber species (Gonystylus bancanus). Plant Mol. Biol. Rep. 23: 185-192. https://doi.org/10.1007/BF02772709.

Bessetti J (2007). An Introduction to PCR inhibitors Promega Notes.

Broberg M and McDonald JE (2019). Extraction of microbial and host DNA, RNA, and proteins from Oak Bark Tissue. Methods Protoc. 2: 15-21. https://doi.org/10.3390/mps2010015.

Cingilli H and Akcin A (2005). High quality DNA isolation method for Chickpea Genotypes. Turk. J. Biol. 29: 1-5.

Collard BCY and Mackill DJ (2009). Start Codon Targeted (SCOT) polymorphism: a simple, Novel DNA Marker Technique for Generating Gene-Targeted Markers in Plants. Plant Mol. Biol. Rep. 27: 86-93. https://doi.org/10.1007/s11105-008-0060-5.

Cota-Sánchez JH, Remarchuk K and Ubayasena K (2006) Ready-to-use DNA extracted with a CTAB method adapted for herbarium specimens and mucilaginous plant tissue. Plant Mol. Biol. Rep. 24: 161-167. https://doi.org/10.1007/BF02914055.

Demeke T and Adams RP (1992). The effects of plant polysaccharides and buffer additives on PCR. Biotechniques. 12: 332-334.

El-Aziz MHA, Mohamed SY and Magwaid HE (2019). Molecular and phytochemical assessment for some seedy strains of Alamar apricot rootstock under salinity stress. Egyp. J. Basic. Appl. Sci. 6: 173-186. https://doi.org/10.1080/2314808X.2019.1690358.

Fatima T, Srivastava A and Hanur V (2018) An effective wood DNA extraction protocol for three economic important timber species of India. Am. J. Plant Sci. 9: 139-149. https://doi.org/10.4236/ajps.2018.92012. 
Finkeldey R, Leinemann L and Gailing O (2010). Molecular genetic tools to infer the origin of forest plants and wood. Appl. Microbiol. Biotechnol. 85: 1251-1258. https://doi.org/10.1007/s00253-009-2328-6.

Hartvig I, Czako M, Kjær ED, Nielsen LR, et al. (2015). The Use of DNA Barcoding in Identification and Conservation of Rosewood (Dalbergia spp.). PLoS one. 10(9): e0138231. https://doi.org/10.1371/journal.pone.0138231.

Hebert PDN, Cywinska A, Ball SL and deWaard JR (2003). Biological identifications through DNA barcodes. Proc. Biol. Sci. 270: 313-321. https://doi.org/10.5772/49967.

Heikrujam J, Kishor R and Mazumder PB (2020). The Chemistry Behind Plant DNA Isolation Protocols. Biochem. Anal. Tools - Methods Bio-Mol. Stud. https://doi.org/10.5772/intechopen.92206.

Horne EC, Kumpatla SP, Patterson KA, Gupta M, et al. (2004) Improved protocols for high-throughput sunflower and cotton genomic DNA extraction and PCR fidelity. Plant Mol. Biol. Rep. 22: 83-84. https://doi.org/10.1007/BF02773352.

Jiao L, Yin Y, Xiao F, Sun Q, et al. (2012). Comparative analysis of two DNA extraction protocols from fresh and dried wood of Cunninghamia lanceolata (Taxodiaceae). JAWA J. 33: 441-456. https://doi.org/10.1163/2294193290000106.

Kalinowska E, Chodorska M, Paduch-Cichal E, Mroczkowska K, et al. (2012). An improved method for RNA isolation from plants using commercial extraction kits. Acta Biochim. Pol. 59: 391-393. https://doi.org/10.18388/abp.2012 2127.

Lewis GP (2005) Legumes of the world. Royal Botanic Gardens, Kew, Richmond, UK.

Li G and Quiros C (2001). Sequence-related amplified polymorphism (SRAP), a new marker system based on a simple PCR reaction: its application to mapping and gene tagging in Brassica. Theor. Appl. Genet. 103: 455-461. https://doi.org/10.1007/s001220100570.

Liangsiri C, Tiyanon P, Suebkha A and Kittibanpacha S (1993). Siamese Rosewood in Reforestration. Reforestation Promotion Office, Department of Forestry, Bangkok.

Lock JM and Heald J (1994). Legumes of Indo-China: a check-list. Royal Botanic Gardens, Kew, Richmond, England.

Niyomdham C, Ho P, DyPhon P and Vidal J (1997). Leguminoseae-Papilionoideae Dalbergieae. Muséum National d'HistoireNaturelle, Paris.

Niyomdham C (2002). An account of Dalbergia (Leguminosae-Papilionoideae) in Thailand. Thai For. Bull. (Bot) 30: 124-166.

Novaes RML, Rodrigues JG and Lovato MB (2009). An efficient protocol for tissue sampling and DNA isolation from the stem bark of Leguminosae trees. Genet. Mol. Res. 8(1): 86-96. https://doi.org/10.4238/vol8-1gmr542.

Pipan B, Zupančič M, Blatnik E, et al. (2018). Comparison of six genomic DNA extraction methods for molecular downstream applications of apple tree (Malus domestica). Cogent Food Agric. 4(1): 1540094 https://doi.org/10.1080/23311932.2018.1540094.

Poland JA, Brown PJ, Sorrells ME, et al (2012). Development of high-density genetic maps for barley and wheat using a novel two-enzyme genotyping-by-sequencing approach. PLoS One. https://doi.org/10.1371/journal.pone.0032253.

Porebski S, Bailey LG and Baum BR (1997). Modification of a CTAB DNA extraction protocol for plants containing high polysaccharide and polyphenol components. Plant Mol. Biol. Rep. 15: 8-15 https://doi.org/10.1007/BF02772108.

Rachmayanti Y, Leinemann L, Gailing O, Finkeldey R, et al. (2006). Extraction, amplification and characterization of wood DNA from dipterocarpaceae. Plant Mol. Biol. Rep. 24: 45-55. https://doi.org/10.1007/BF02914045.

Robarts DWH and Wolfe AD (2014). Sequence-related amplified polymorphism (SRAP) markers: a potential resource for studies in plant molecular biology 1. Appl. Plant Sci. 2: apps.1400017. https://doi.org/10.3732/apps. 1400017.

Sablok GPG, Gupta A, Pareek K and Shekhawat N (2009). Extraction of PCR-usable DNA using modified CTAB method from the Resource Trees adapted to arid environment sustainability. Plant Omics. 2(3): 103-109.

Sambrook JF and Russell DW (2001). Molecular cloning: a laboratory manual; 3 vols. Cold Springs Harbour Press, New York.

Sahu SK, Thangaraj M and Kathiresan K (2012). DNA extraction protocol for plants with high levels of secondary metabolites and polysaccharides without using liquid nitrogen and phenol. ISRN Mol. Biol. 2012: 205049 https://doi.org/10.5402/2012/205049.

Schrader C, Schielke A, Ellerbroek and Johne R (2012). PCR inhibitors - occurrence, properties and removal. J. Appl. Microbiol. 113: 1014-1026 https://doi.org/10.1111/j.1365-2672.2012.05384.x.

Sheikh PA and Corn ML (2016). The Convention on International Trade in Endangered Species of Wild Fauna and Flora (CITES): Congressional Research Service: Informing the Legislative Debate Since 1914. Government of South Africa, Johannesburg, South Africa.

Soonhuae P (1993). Estimation of genetic variation in Thailand rosewood (Dalbergia cochinchinensis Pierre). Dissertation, The University of British Columbia (Canada).

Sun Z, Wang Z, Tu J, Zhang J, et al. (2007). An ultradense genetic recombination map for Brassica napus, consisting of 13551 SRAP markers. Theor. Appl. Genet. 114: 1305-1317. https://doi.org/10.1007/s00122-006-0483-z.

Swetha VP, Parvathy VA, Sheeja TE and Bhas S (2014). Isolation and amplification of genomic DNA from barks of Cinnamomum spp. Turk. J. Biol. 38: 151-155. https://doi.org/10.3906/biy-1308-5. 
Tang W, David FB, Wilson MM, Barwick BG, et al. (2009). DNA Extraction from formalin-fixed, paraffin-embedded tissue. Cold Spring Harb Protoc. 2009: pdb.prot 5138. https://doi.org/10.1101/pdb.prot5138.

Vane CH, Drage TC and Snape CE (2006). Bark decay by the white-rot fungus Lentinula edodes: Polysaccharide loss, lignin resistance and the unmasking of suberin. Int. Biodeterior. Biodegradation. 57: 14-23 https://doi.org/10.1016/j.ibiod.2005.10.004.

Wangsomnuk PP, Rittithum W and Ruttawat B (2014). Comparative analysis of DNA extracted from mature leaves of rubber tree and application for amplification. AAB Bioflux 6(1): 45-57.

Webb CO, Slik JWF and Triono T (2010). Biodiversity inventory and informatics in Southeast Asia. Biodivers. Conserv. 19: 955-972. https://doi.org/10.1007/s10531-010-9817-x.

Yu M, Jiao L, Guo J, Wiedenhoeft AC, et al. (2017). DNA barcoding of vouchered xylarium wood specimens of nine endangered Dalbergia species. Planta. 246(6): 1165-1176. doi: 10.1007/s00425-017-2758-9. 